\title{
異常対応外斜視とその治療経験
}

\section{江口寿々子・田中典子・久川加代子 富山淑子・小倉洋子(帝京大)}

\section{Prism Treatment for Abnormal Retinal Correspondence}

\author{
Suzuko EGUCHI, Noriko TANAKA, Kayoko HISAKAWA \\ Yoshiko TOMIYAMA and Yoko OGURA \\ Department of Ophthalmology, Teikyo University School of Medicine
}

\section{I. 緒言}

網膜異常対忘には種々の考え方があるが，両 眼の中心窩同士が対忘せず，固視眼の中心窩と 偏位眼の中心窩以外の網膜とが対忘寸る網膜異 常対応で; 術前の forced duction test で眼位を正位に 寸ると背理性複視が強く自覚される場合，手術は できない。しかし眼位矯正を強く希望寸る患者 もあり，これらの網膜異常対忘をもつ患者に手 術をできるようにするために，種々の視能矯正 法が試みら机ているが，私達は術前の訓練とし て，プリズム療法を試みてみたのでその結果を 報告したい.

\section{II. 症例}

症例 $/ .16$ 歳, 女子

初診: 昭和5/年/月29日

主訴：眼位矯正

現病歴：2 歳頃, 内斜視に気づき; 6 歳の時 に他医にて内斜視の手術(左眼内直筋後転術と 思われる）を受けている。/2歳頃より外斜視 に気つき，目立つてきたため某大学病院を受診 したところ, 術後複視が出るため手術が難しい と言わ机，当院を紹介されて来院した。

\section{連絡先 ( $=173$ ) 東京都板橋区加賀 2-11-1}

Key Words: Prism treatment, abnormal retinal correspondence, forced duction test, diplopia, constant exotropia.
現症：

$$
\begin{aligned}
V d= & 1.0\left(1.2 \times+0.75 \mathrm{D}=c y 1+1.00 \mathrm{DA} 90^{\circ}\right) \\
V s= & 0.8(1.2 \times+1.25 \mathrm{D}=\mathrm{cyl}+1.250 \\
& \text { A } \left.90^{\circ}\right)
\end{aligned}
$$

眼位は恒常性外斜視, 眼球運動は正常範囲, 透光体, 眼底ともに異常ない。両眼視機能は次 のとおうである，大型弱視鏡において交代視を していて交叉感がなく，同時視が認められない。 Bagolini SG test, Worth 4 灯法, 残像法でも網膜対 忘がはつきりしない。そこで diplopia testを行な

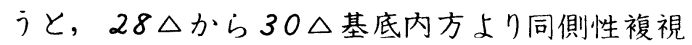
が現れた. Forced duction testにおいても，一10位 にすると同側性複視が現れ，正位に寸るとより複 視がとどくなつた。よつて不調和性異常対応と 診断し，複視の限界まで手術することにした。 一1 $0^{\circ}$ 位を目的に, 右眼内直筋前転術を施行し た。術後，眼位はー10の外斜視で複視はなか つた。年の後, 受験などで本人が忙しく来院せ ず，3年後，外斜視が気になつたため再び来院 した。この時の眼位は一 $15^{\circ}$ の外斜視，両眼視 機能は異常対忘であつた。本人は強く眼位矯正 を希望したので，術後の背理性複視に慣らすた めに，フレネル膜プリズムによる訓練を始める ことにした。30 基底内方のフレネル膜プリ ズムを両眼に分けて処方し，家庭で每日2時間 位訓練した。/カ月後の来院時には複視は近見 ではなくなク，遠見では少し残つているような 
感じとなつた。さらに訓練を続け，4 カ月後に は遠見，近見ともに複視が殆ど気にならなくな つた. Forced duction testでも, 正位にしても同じよ うに複視が気にならないので，54年10月2日， 左眼内直筋前転術, 外直箭後転術5 mm 施行 L た。術後, 複視は消之, 6 力月後の来院時には 眼位一 $4^{\circ}$ の外斜視, 複視はやはりなかつた。

症例 2. 21 歳, 男子

初診：昭和52年5月10日

主訴：眼位矯正

現病歴：生来外斜視に気づいていたが，放置 していた。眼位矯正を希望し，来院した。

現症：

$$
\begin{aligned}
& V d=\left(0.5 \times-4.0 \mathrm{D}=\mathrm{cyl}-3.5 \mathrm{DA} 20^{\circ}\right) \\
& V s=\left(0.7 \times-2.0 \mathrm{D}=\mathrm{cyl}-5.0 \mathrm{DA} / 70^{\circ}\right)
\end{aligned}
$$

眼位は恒常性外斜視, 眼球運動は上方注視不 能を認め, 透光体, 眼底ともに異常ない. 雨眼視機 能は次のとおりである。.大型弱視鏡において交代 視をしていて交叉感がなく，同時視が認められな い. Bagolini SG test, Worth 4 灯法, 残像法でも, 網 膜对応がはつきりしない，そこで-diplopia testを行

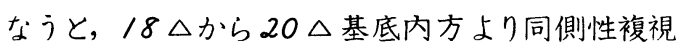
が現れた. Forced duction testにおいても，一20位 にすると同側性複視が現れ，正位にするとより 複視がひどくなつた。よつて不調和性異常対态 と診断し，術後の背理性複視に慣らすために， フレネル膜プリズムによる訓練を始めることに した６0○基底内方のフレネル膜プリズムを 両眼に分けて処方し, 家庭で每日/時間から4 時間位訓練した。3カ月半後の来院時には, 複視 が近見ではあつたりなかつたり，遠見では複視の距 離が装用開始時より近くなり，4 力月半後には 近見では複視は消え，遠見ではあつたりなかつ たクだつた。さらに6カ月後には，遠見で時々 複視を自覚するのみとなつた。この症例につい ては，残念ながら患者の都合で手術!さできなか つた.

\section{III. 考按}

網膜異常対応というと斜視における感覚性適 忘の/つとされ，今だにすつきクした定義もな く進歩もない上うだが，抑制暗点の存在，微小 角異常との関連などこれからおおいに研究して,
検討していくべきものと思われる. 今回，私達が経 験した異常対态について，まず症例/および2 の異常対态の判定基準から述へててたい。症例 /および2ともに大型弱視鏡, Bagolini SG test, Worth 4灯法, 残像法による網膜対応検査の結 果がはつきりしない。そこで diplopia test, forced duction testにより，正位にした時の自覚的な複視の 認知により, 術後の背理性複視予想のもとに, 不 調和性異常対応と判定した. 一方, 異常対応の治 療には遮閉法，プリズム，あるいは手術で眼位 矯正寸ることによる方法, 両眼同相 Coordinator を用いる方法，日常空間視における訓練などい ろいろある．感覚面において，異常対応を正常対 応一もつてゆく視能訓練がある一方, 術後の背 理性複視のことも大きな問題である。眼位が良 くなつても，患者が複視による苦痛をもてば何 にもならない，今回の症例は眼位矯正を強く希 望しており，年齢も高かつたことなどから，異 常対応そのものの視能訓練は行なつていない. 私達は，眼位矯正を主目的とした異常対応の治 療を検討した。私達は, 術後の背理性複視にな らすために，フレネル膜プリズムを使用した。 プリズムによる治療は，眼精疲労を伴う斜位の 治療, 抑制の除去, 異常対态の治療, 残余斜視 の治療などがあるが，フレネル膜プリズムは眼 鏡レンズに簡単に貼付交換でき，軽く，外観上 勝れている，大角度にも処方できるなどの点で， このような視能訓練に使用されている。私達が 今回経験した異常対忘の治療は, 患者が一番希 望した眼位矯正を可能にした。このことは喜ぶ べきことで，今後更に検討してゆく必要がある $と$ 思j。一方, 異常対态の患者に対寸る根本的 治療としての視能訓練にも正面からとりくんで いきたいと考えている。

\section{$\mathbf{N}$ 結 論}

私達は, 眼位矯正を主目的として来院した異 常対忘を併せもつ斜視患者2例に対し，フレネ ル膜プリズムを使用して, 術後の背理性複視の 軽減をはかるという方法をとつた。フレネル膜 プリズムは家庭訓練を可能にし，それも数力月 の訓練でかなりの効果をあげることができた。 丸尾敏夫教授の御指導, 御校閲と, 久保田伸 
枝助教授の御教示を深く感謝いたします。

文献

Levinge, M.: A changed approach to abnormal retinal correspondence. Brit. Orthopt. J., 10: 10, 1953.

Maurer, Y.: Abnormal retinal correspondence. Brit. Orthopt. J., 12: 48, 1955.

Kukora, J. S.: Anomalous retinal correspondence diagnostic test and therapy. Am. Orthopt. J., 6: 90, 1956.

Koehler, V. D.: Preoperative orthoptics for esotropia with abnormal retinal correspondence. Am. Orthopt. J., 12: $55,1962$.
Gaffney, R. B.: Anomalous retinal correspondence. Am. Orthopt. J., 15: 112, 1965.

植村恭夫：網膜異常対応と微少斜視. 眼科, 12 : $198,1970$.

井上浩彦・市田忠栄子：プリズム装用に関寸る 吟味. 眼科, /4：359, /972.

深井小久子：異常対応の視能矯正。眼科, 16: / /5, 1974 .

植村恭夫：斜視患者における最近の動向. 日本 視能訓練士協会会報， 4 ：1, / 975 .

馬嶋 孝・半田喜久美：フレネル膜プリズムに よる斜視の治療。眼科, 20：28/, 1978.

\section{アルジェリア国医療協カプロジェクトの一部である 視能矯正学を指導して}

\section{三柴恵美子（北里大）}

As a Instractor of the Orthoptics in Algeria

Emiko MISHIBA

Department of Ophthalmology; Kitasato University School of Medicine

\section{I. 緒言}

1978年12月より/年間, 外務省の外郭団 体である国際協力事業団医療協力部の要請によ ク，アルジェリア国オラン市に建設中のオラン 科学技術総合大学に, 医師 / 名, 視能訓練士2 名が派遣された。このアルジェリア医療協力プ ロジェクトは5年計画で始まク, 眼科の他染色 体及び小児科の技術援助もさ机る予定である。

連絡先（† 228）相模原市麻溝台 I
ここで, 北アフリカに位置するアルジェリアに ついて簡単に紹介しておこう。国土面積は238 万1.74 $\mathrm{km}^{2}$ で日本の約6.3 倍と広大であるが， 居住に適した面積は限られていて人口は地中海 に面した緑地带に密集している。気候は地中海 気候, 草原気候, そして大部分を占める砂漠気 候に分けられる。言語は公用語としてアラビア 語, 準公用語としてフランス語が使われている. 風俗，習慣とも日本と異なるところが多い。宗 教はイスラム教である。アルジェリアは/962 